Akuntabilitas: Jurnal Ilmu Akuntansi

Volume 9 (I), April 2016

P-ISSN: 1979-858X; E-ISSN: 246I-II 90

Page 73 - 96

\title{
KINERJA KEUANGAN PERUSAHAAN ASURANSI SYARIAH DI INDONESIA: SURPLUS ON CONTRIBUTION
}

\author{
Ai Fitri Nurlatifah \\ Sepky Mardian \\ Sekolah Tinggi Ekonomi Islam SEBI \\ sepky.mardian@gmail.com
}

\begin{abstract}
This study aims to identify the impact of size, leverage, liquidity, tangibility, volume of capital and loss ratio on the financial performance of Sharia Insurance Companies in Indonesia as measured by Surplus On Contribution (SOC) from 2012 to 20I4. The data analysis technique used is panel data regression with a significance level of $5 \%(0.05)$. Results of the data analysis showed that the right model used in this study is the Fixed Effects Model (FEM). Simultaneously the six variables significantly influence the good financial performance as measured by SOC. Partially; the size $(0.0000)$ has a positive influence on the financial performance (SOC), whereas leverage (0.0167) and volume of capital (0.0000) negatively affect performance finance (SOC). Liquidity variable (0.8552), tangibility $(0.5513)$ and loss Ratio $(0.986 \mathrm{I})$ did not have a significant effect on the financial performance (SOC).
\end{abstract}

Keywords: Financial performance, Surplus On Contribution (SOC), size, leverage, liquidity, tangibility, volume of capital, and loss ratio

\begin{abstract}
Abstrak
Penelitian ini bertujuan untuk mengetahui faktor size, leverage, liquidity, tangibility, volume of capital dan loss ratio terhadap kinerja keuangan perusahaan-perusahaan asuransi syariah di Indonesia yang diukur dengan Surplus On Contribution (SOC) dari tahun 2012 sampai tahun 2014. Teknik analisis data yang digunakan adalah regresi data panel dengan tingkat signifikansi $5 \%(0,05)$. Hasil analisis data menunjukan bahwa model yang tepat digunakan dalam penelitian ini adalah Fixed Effect Model (FEM). Secara simultan keenam variabel tersebut berpengaruh signifikan terhadap kinerja keuangan baik yang diukur oleh SOC. Secara parsial, size $(0,0000)$ memiliki pengaruh positif terhadap kinerja keuangan (SOC), sedangkan leverage $(0,0167)$ dan volume of capital $(0,0000)$ berpengaruh negatif terhadap kinerja keuangan (SOC). Variabel liquidity $(0,8552)$, tangibility $(0,55 / 3)$ dan loss ratio $(0,9861)$ tidak memiliki pengaruh yang signifikan terhadap kinerja keuangan (SOC).

Kata Kunci: Kinerja keuangan, Surplus On Contribution (SOC), size, leverage, liquidity, tangibility, volume of capital, dan loss ratio
\end{abstract}

Diterima: I5 Januari 2016; Direvisi: 20 Februari 20I6; Disetujui: I5 Maret 2016 


\section{PENDAHULUAN}

Perkembangan dunia usaha yang semakin baik di era globalisasi ini mengakibatkan persaingan dunia usaha tersebut menjadi sangat ketat. Oleh karena itu, sebuah perusahaan harus memiliki keunggulan kompetitif agar mampu meningkatkan kinerja yang dimilikinya. Sehingga mampu menghasilkan profit maksimal untuk menjamin kelangsungan hidup dan perkembangan perusahaan dimasa yang akan datang (Putri \& Lestari, 20I4). Kinerja perusahaan adalah pengukuran prestasi yang telah dicapai oleh perusahaan dari hasil aktivitasnya, yang menunjukan kondisi baik dalam jangka waktu tertentu. Tujuan dari pengukuran prestasi ini adalah untuk memberikan informasi berguna terkait dengan aliran dana, penggunaan dana, efektivitas dan efisiensi. Ukuran yang dipilih untuk menilai kinerja sebuah perusahaan tergantung dari jenis perusahaan yang akan dievaluasi dan hasil yang ingin dicapai dari penelitian tersebut (Almajali, 20I2).

Menurut Ahmed (2010) kinerja perusahaan tidak hanya memainkan peran untuk meningkatkan nilai pasar perusahaan tertentu. Tetapi lebih mengarah ke arah pertumbuhan industri seluruh sektor, yang akhirnya akan mengarah pada kemakmuran ekonomi secara keseluruhan. Pada umumnya kinerja terbaik sebuah perusahaan dapat dilihat melalui profitabilitas dari suatu laporan keuangan perusahaan. Profitabilitas adalah salah satu tujuan paling penting dari manajemen keuangan yaitu untuk memaksimalkan kekayaan owner (para pemegang saham). Profitabilitas juga merupakan faktor penentu kinerja sebuah perusahaan yang sangat penting (Malik, 20I I).

Sektor asuransi memainkan peran penting dalam ekonomi berbasis layanan. Bertindak sebagai lembaga perantara keuangan yang telah terintegrasi ke dalam industri keuangan yang lebih luas (Malik, 20II). Berbicara mengenai asuransi, Allah telah memerintahkan manusia agar mampu menyiapkan bekal (proteksi) untuk kepentingan di masa depan supaya segala hal negatif baik dalam bentuk musibah, kecelakaan, kebakaran atau kematian dapat diminimalisir kerugiannya (Pusat Komunikasi Ekonomi Syariah, 2008). Hal tersebut telah dicontohkan oleh Nabi Yusuf (QS. Yusuf : 46-49) ketika menakwilkan mimpi Raja Mesir tentang tujuh ekor 
sapi betina gemuk dimakan oleh tujuh sapi betina kurus yang memberikan pelajaran agar manusia mengadakan persiapan untuk menghadapi masa-masa sulit.

Menurut data dari Instituto Financeiro Para O Desenvolvimento Regional (IFDR) tahun 2013, industri asuransi syariah di Indonesia menempati posisi keempat dunia (Mysharing.co, 2015) dan terus membuktikan perkembangan yang signifikan meskipun pertumbuhan ekonomi Indonesia belakangan ini sedang mengalami perlambatan.

Persaingan perusahaan asuransi syariah semakin ramai dengan bermunculannya pemain-pemain baru. Mulai dari asuransi jiwa syariah sampai asuransi umum/kerugian syariah. Sementara perusahaan reasuransi, meskipun tidak mengalami penambahan dari segi jumlah, tetapi dari segi kontribusi dan inovasi produk terus mengalami peningkatan (Karim Consulting Indonesia, 20I4). Sejak berdirinya asuransi syariah pertama tahun 1994 yaitu Asuransi Takaful Keluarga dan Asuransi Takaful Umum sampai saat ini jumlah asuransi syariah berjumlah 52 perusahaan. Berikut ini adalah tabel jumlah perusahaan asuransi syariah di Indonesia:

Berdasarkan data dapat diketahui sampai bulan Agustus 2015 jumlah asuransi jiwa syariah full fledge bertambah satu dari tahun sebelumnya menjadi 4 perusahaan. Asuransi jiwa unit syariah bertambah 2 perusahaan dari 17 menjadi 19 perusahaan. Perusahaan asuransi umum syariah full fledge bertambah I dari tahun sebelumnya menjadi 3 perusahaan. Sedangkan untuk asuransi umum unit syariah dan reasuransi tidak mengalami penambahan dari segi jumlah. Selain dari sisi kuantitas, asuransi syariah juga mengalami pertumbuhan baik dari segi aset, investasi, kontribusi maupun klaim. Untuk lebih jelasnya, bisa dilihat pada tabel berikut ini :

Sampai bulan Agustus tahun 2015 jumlah aset asuransi syariah berjumlah 24 triliun rupiah naik sebesar $24 \%$ dari tahun sebelumnya. Pertumbuhan terbesar dialami oleh reasuransi syariah dimana mengalami kenaikan sebesar $37 \%$ menjadi I triliun rupiah. Berbanding lurus dengan pertumbuhan aset asuransi syariah, investasi asuransi syariah juga mengalami kenaikan sebesar $27 \%$ menjadi 21 triliun rupiah. Pertumbuhan terbesar masih pada reasuransi syariah yang naik menjadi $44 \%$ dari tahun sebelumnya. Total kontribusi (premi syariah) naik 15\% sementara klaim naik menjadi 22\% (IKNB, 20I5). 
Meskipun industri asuransi syariah mengalami perkembangan dari segi jumlah, total aset, total investasi, kontribusi serta klaim, akan tetapi hal ini belum bisa menyaingi perusahaan asuransi konvensional dari segi pangsa pasar. Hal ini bisa dibuktikan dari market share kontribusi asuransi syariah yang hanya mencapai 5,03\% dari total premi nasional. Market share kontribusi asuransi jiwa syariah hanya $7,79 \%$ serta market share kontribusi asuransi umum syariah hanya $1,98 \%$ dari premi nasional (IKNB, 20I5). Sedangkan market share aset asuransi syariah secara umum mengalami penurunan pada tahun 2014 sebesar $2 \%$ dari 4,28\% pada tahun sebelumnya (2013) menjadi 4,19\% (Karim Consulting Indonesia, 2014). Menurut Hasbi (20/3), hal ini menandakan adanya masalah pada instrumen keuangan berbasis syariah, apakah disebabkan karena produk asuransi syariah yang tidak menarik atau karena kinerja perusahaan asuransi syariah yang rendah sehingga masyarakat masih belum percaya terhadap asuransi berbasis syariah. Pangsa pasar sendiri dapat ditingkatkan dengan melakukan kinerja terbaik.

Tidak banyak studi yang dilakukan untuk menyelidiki faktor-faktor penentu kinerja perusahaan asuransi syariah, khususnya di Indonesia. Penelitian sebelumnya yang dilakukan oleh Malik (20II) menjelaskan faktor-faktor yang mempengaruhi profitabilitas perusahaan asuransi di Pakistan dimana size (ukuran perusahaan) dan volume of capital berpengaruh positif terhadap Return On Asset (ROA). Hal ini menjelaskan bahwa size dan volume of capital merupakan faktor penting dalam menentukan kinerja perusahaan asuransi. Sedangkan age of company (umur perusahaan) loss ratio dan leverage ratio tidak memiliki pengaruh terhadap kinerja keuangan yang diukur dengan ROA.

Penelitian Almajali (2012), menjelaskan tentang faktor-faktor yang mempengaruhi kinerja keuangan perusahaan asuransi di Yordania yang terdaftar di Amman Stock Exchange (ASE) menunjukan leverage, liquidity, size, management competence index (indeks kompetensi manajemen) berpengaruh positif terhadap ROA yang berarti bahwa leverage, liquidity, size, management competence index adalah faktor penting dalam menentukan kinerja keuangan perusahaan asuransi di Yordania. 
Pada penelitian yang dilakukan oleh Mehari \& Aemiro (2013), diketahui bahwa size (ukuran perusahaan), tangibility (aset tetap), leverage dan loss ratio (risiko kerugian) berpengaruh positif terhadap ROA dan merupakan penentu penting kinerja perusahaan asuransi di Ethiopia. Sedangkan growth in writing premium, age dan likuiditas tidak berpengaruh terhadap ROA.

Penelitian lain yang dilakukan oleh Putri \& Lestari (20l4), menjelaskan tentang faktor spesifik yang menentukan kinerja perusahaan asuransi yang terdaftar di Bursa Efek Indonesia (BEI) dimana size berpengaruh positif dan leverage berpengaruh negatif terhadap financial performance. Sedangkan age, tangibility, loss ratio, liquidity, premium growth tidak berpengaruh terhadap financial performance.

Sejalan dengan masalah market share asuransi syariah yang tidak mengalami pertumbuhan secara signifikan, padahal dari sisi jumlah, aset, investasi, kontribusi serta klaim mengalami pertumbuhan, maka penelitian ini menarik untuk dilakukan dalam menganalisis faktor-faktor yang mempengaruhi kinerja keuangan asuransi syariah di Indonesia dengan menggunakan variabel-variabel yang berpengaruh positif terhadap kinerja keuangan perusahaan asuransi pada penelitian sebelumnya, yaitu menggunakan variabel size, leverage, liquidity, tangibility, volume of capital dan loss ratio yang diukur oleh Return On Asset (ROA).

Dalam penelitian ini, ROA digunakan sebagai ukuran untuk mengukur kinerja perusahaan asuransi syariah di Indonesia. Return on aset (ROA) dihitung dari laba bersih sebelum pajak dengan total aktiva. Sejak analisis untuk ROE tidak memperhatikan terkait dengan risiko leverage yang tinggi dan leverage sendiri sering ditentukan oleh peraturan, ROA muncul sebagai rasio kunci untuk mengevaluasi profitabilitas.

ROA adalah rasio yang paling penting dalam membandingkan efisiensi dan kinerja keuangan perusahaan asuransi. Hal ini disebabkan karena rasio ini mencerminkan kemampuan manajemen untuk memanfaatkan sumber daya investasi untuk menghasilkan keuntungan secara keseluruhan (Mehari \& Aemiro, 2013). Selain menggunakan ROA, penulis juga menggunakan alat ukur Surplus On Contribution (SOC) dalam menghitung kinerja keuangan perusahaan asuransi syariah di Indonesia. Menurut Mokhtar, Aziz, \& Hilal (2015) semakin tinggi surplus yang 
terdapat di perusahaan asuransi syariah maka akan semakin tinggi pula tingkat kompetitif (kinerja) di perusahaan asuransi tersebut. Surplus yang efektif tidak hanya akan membantu eksistensi perusahaan asuransi syariah dalam jangka panjang, akan tetapi hal ini juga bisa menarik nasabah untuk bisa berasuransi diperusahaan asuransi syariah. Penggunaan SOC sebagai alat ukur dalam menilai kinerja keuangan asuransi syariah sendiri, menjadi pembeda dari penelitian-penelitian sebelumnya yang hanya menggunakan ROA.

Pentingnya melakukan penelitian ini menurut Mehari \& Aemiro (2013) adalah untuk mengisi kesenjangan yang penting dalam memahami faktor penentu kinerja bagi perusahaan asuransi dalam ekonomi berkembang. Ahmed (2010) menyatakan bahwa pentingnya menilai kinerja perusahaan asuransi adalah karena perusahaan asuransi tidak hanya sekedar menyediakan mekanisme transfer risiko, tetapi sebagai perantara dalam menyalurkan dana dengan cara yang tepat untuk membantu mendukung usaha dalam kegiatan perekonomian. Berdasarkan uraian diatas, kinerja perusahaan merupakan informasi yang sangat penting bagi semua pihak pengambil keputusan untuk memotivasi dalam membuat keputusan terbaik (Putri \& Lestari, 20I4).

Selain itu, pentingnya melakukan penelitian ini adalah terkait dengan penetrasi industri asuransi syariah di Indonesia yang masih sangat rendah. Menurut OJK, sampai bulan September 2015 penetrasi asuransi syariah baru mencapai 0,08\% Angka tersebut menunjukkan perbandingan total premi bruto asuransi syariah terhadap Pendapatan Domestik Bruto (PDB) dimana nilai premi per kapita (densiti) Indonesia masih sangat rendah, yaitu baru mencapai 40.000 (Hana, 20I5).

\section{KERANGKA TEORITIS DAN PENGEMBANGAN HIPOTESIS}

\section{Asuransi Syariah}

Dalam bahasa arab istilah asuransi biasa diungkapkan dengan kata at-ta'min yang secara bahasa berarti tuma'niatun nafsi wa zawalul khauf, tenangnya jiwa dan hilangnya rasa takut. Maksudnya, orang yang ikut dalam kegiatan asuransi, jiwanya akan tenang dan tidak ada rasa takut ataupun was-was dalam menjalani kehidupan, karena ada pihak yang memberikan jaminan atau pertanggungan (Hosen, Ali, \& Muhtasib, 2008). 
Pengertian asuransi syariah menurut Fatwa DSN MUI (200I), yang lebih dikenal dengan ta'min, takaful, atau tadhamun adalah usaha saling melindungi dan tolong menolong diantara sejumlah orang atau pihak melalui investasi dalam bentuk aset dan atau dana tabarru' yang memberikan pola pengembalian untuk menghadapi risiko tertentu melalui akad yang sesuai dengan syariah. Asuransi berdasarkan prinsip syariah menurut PMK No. 18 dan No. 10 (2010) adalah usaha saling tolong menolong (ta'awuni) dan melindungi (takafuli) diantara para peserta melalui pembentukan kumpulan dana (dana tabarru') yang dikelola sesuai prinsip syariah untuk menghadapi risiko tertentu.

\section{Kinerja Keuangan}

Kinerja (performance) adalah gambaran mengenai tingkat pencapaian pelaksanaan suatu kegiatan/program/kebijakan dalam mewujudkan sasaran, tujuan, misi, dan visi organisasi yang tertuang dalam strategic planning suatu organisasi. Kinerja adalah fungsi dari kemampuan organisasi untuk mendapatkan dan mengelola sumber daya dalam beberapa cara yang berbeda untuk mengembangkan keunggulan kompetitif. Ada dua jenis kinerja, kinerja keuangan dan kinerja non-keuangan (Hanson \& Mowen, 2005) dalam Almajali (2012). Literatur biasanya membedakan antara dua jenis kinerja perusahaan, keuangan atau kinerja ekonomi dan kinerja yang inovatif. Kinerja keuangan atau ekonomi sering dinyatakan dalam hal pertumbuhan penjualan, omset, pekerjaan, atau harga saham (Havnes \& Senneseth, 200I) dalam Almajali (2012).

Pengukuran kinerja (performance measurement) adalah suatu proses penilaian kemajuan pekerjaan terhadap tujuan dan sasaran yang telah ditentukan sebelumnya, termasuk atas : efisiensi barang dan jasa (seberapa baik barang dan jasa diserahkan kepada pelanggan dan sampai seberapa jauh pelanggan terpuaskan), hasil kegiatan dibandingkan dengan maksud yang diinginkan dan efektivitas tindakan dalam mencapai tujuan (Mahsun, Sulistiyowati, \& Purwanugraha, 20I I).

Pada organisasi bisnis, kinerja penyelenggaranya dapat dilakukan dengan cara misalnya melihat tingkat laba yang berhasil diperolehnya. Apabila pengukurannya ingin ditingkatkan lagi, hal ini dapat dilihat dengan menilai berbagai hal lainnya seperti 
solvabilitas, rentabilitas, return on investment dan sebagainya (Mahsun, Sulistiyowati, \& Purwanugraha, 20II).

\section{Surplus On Contribution (SOC)}

Dalam penelitian Mokhtar, Aziz, \& Hilal (2015) tentang praktek pembagian surplus di Malaysia menjelaskan bahwa surplus on contribution (SOC) digunakan sebagai alat ukur untuk menilai kinerja sebuah perusahaan asuransi syariah. Surplus underwiriting adalah selisih lebih total kontribusi peserta kedalam dana tabarru' setelah dikurangi pembayaran santunan/klaim kontribusi reasuransi dan cadangan teknis, dalam satu periode tertentu (Amanah Githa Asuransi Jiwa Syariah, 2016). Sedangkan kontribusi adalah jumlah bruto yang menjadi kewajiban peserta asuransi yang digunakan untuk membayar klaim atas risiko tertentu akibat musibah pada jiwa, badan, atau benda yang dialami oleh peserta yang berhak serta untuk membayar ujrah. Kontribusi tersebut merupakan milik peserta secara kolektif, bukan merupakan pendapatan entitas pengelola (PSAK 108 Akuntansi Asuransi Syariah, 2008).

Semakin tinggi surplus yang terdapat diperusahaan asuransi syariah menunjukan semakin tinggi pula tingkat kinerja di perusahaan asuransi tersebut. Surplus yang efektif tidak hanya akan membantu eksistensi perusahaan asuransi syariah dalam jangka panjang, akan tetapi hal ini juga bisa menarik nasabah untuk bisa berasuransi diperusahaan asuransi syariah, sehingga pada akhirnya akan meningkatkan pangsa pasar asuransi syariah yang berdampak pada kinerja keuangan asuransi syariah yang semakin meningkat. (Mokhtar, Aziz, \& Hilal, 20I5).

\section{Faktor-Faktor yang Mempengaruhi Kinerja Keuangan Perusahaan}

Leverage utang diukur dengan rasio total utang terhadap ekuitas (debt/equity ratio). Perusahaan yang sangat leverage mungkin berisiko kebangkrutan jika mereka tidak mampu melakukan pembayaran utang mereka juga tidak dapat menemukan pemberi pinjaman baru di masa depan. Penelitian Mehari \& Aemiro (2013) menyebutkan bahwa perusahaan asuransi bisa makmur dengan mengambil risiko leverage yang wajar atau bisa bangkrut jika risikonya diluar kendali.

Liquidity mengacu sejauh mana kewajiban utang yang jatuh tempo dalam 12 bulan ke depan bisa dibayar dari kas atau aset untuk kewajiban lancar (current ratio). 
Menurut Mehari \& Aemiro (2013) perusahaan asuransi dengan aset yang lebih likuid cenderung untuk gagal lebih rendah karena mereka dapat mencairkan kas bahkan dalam situasi yang sangat sulit. Oleh karena itu, perusahaan asuransi yang memiliki aset likuid yang lebih, akan bisa mengungguli perusahaan asuransi yang hanya memiliki sedikit aset likuid.

Ukuran perusahaan mempengaruhi kinerja keuangan dalam banyak cara. Perusahaan besar dapat memanfaatkan skala ekonomi dan ruang lingkup. Menurut Mehari \& Aemiro (2013) ukuran perusahaan berhubungan positif dengan kinerja keuangan, disebabkan karena asuransi besar biasanya memiliki kapasitas yang lebih besar untuk menangani pasar yang merugikan fluktuasi perusahaan asuransi kecil.

Penelitian Mehari \& Aemiro (20I3) menyatakan bahwa aset tetap dalam jumlah yang besar akan meningkatkan kinerja keuangan. Dengan kepemilikan aset tetap dalam jumlah yang banyak akan lebih menguntungkan perusahaan asuransi dibandingkan dengan kepemilikan aset yang lebih sedikit. Dalam penelitian tersebut disebutkan bahwa tangibility memiliki pengaruh positif terhadap financial performance.

Pada penelitian yang dilakukan oleh Malik (20II) menjelaskan bahwa volume modal memiliki pengaruh signifikan dalam meningkatkan kinerja perusahaan asuransi. Volume of capital adalah volume modal yang diukur dari nilai buku ekuitas perusahaan.

Penelitian yang dilakukan oleh Malik (20II), menjelaskan bahwa rasio yang paling banyak digunakan untuk mengukur kinerja operasi adalah rasio kerugian dan rasio beban. Rasio kerugian (loss ratio) adalah persentase dari total dolar premium yang dibayar untuk klaim pada jenis tertentu untuk jangka waktu yang panjang.

\section{Hipotesa Penelitian}

Perumusan uji hipotesis dalam penelitian ini mengacu pada hipotesis penelitian sebelumnya (empirical literature), yaitu sebagai berikut :

HI: Size (ukuran perusahaan) memiliki pengaruh positif terhadap kinerja keuangan perusahaan asuransi syariah di Indonesia.

$\mathrm{H} 2$ : Leverage memiliki pengaruh positif terhadap kinerja keuangan perusahaan asuransi syariah di Indonesia. 
H3: Liquidity memiliki pengaruh positif terhadap kinerja keuangan perusahaan asuransi syariah di Indonesia.

H4: Tangibilty (aset tetap) memiliki pengaruh negatif terhadap kinerja keuangan perusahaan asuransi syariah di Indonesia.

H5: Volume of capital memiliki pengaruh positif terhadap kinerja keuangan perusahaan asuransi syariah di Indonesia.

H6: Loss ratio memiliki pengaruh negatif terhadap kinerja keuangan asuransi syariah di Indonesia.

\section{METODE}

Penelitian ini dilakukan untuk mencari tahu hubungan antara variabel independen yaitu size, leverage, liquidity, tangibility, volume of capital, dan loss ratio terhadap variabel dependen yaitu kinerja keuangan yang diukur dengan SOC.

Populasi yang diambil dalam penelitian ini adalah perusahaan asuransi syariah di Indonesia, yaitu asuransi jiwa syariah, asuransi umum syariah serta reasuransi syariah baik yang sudah full fledge maupun yang masih berbentuk asuransi unit syariah berjumlah 52 perusahaan. Adapun pengambilan sampel dalam penelitian ini menggunakan teknik purposive sampling dengan kriteria sebagai berikut:

I. Jumlah asuransi syariah di Indonesia berjumlah 52 perusahaan.

2. Asuransi syariah yang tidak mempublikasikan laporan keuangan publikasi tahunan dari tahun 20I2-20I4 berjumlah I perusahaan.

3. Asuransi syariah yang tidak lengkap mempublikasikan laporan keuangan publikasi tahunan dari tahun 2012-20I4 berjumlah 21 perusahaan.

Berdasarkan kriteria diatas, maka sampel perusahaan asuransi yang dijadikan objek penelitian hanya berjumlah 30 perusahaan. Hal ini juga disebabkan karena regulator $(\mathrm{OJK})$ tidak bersedia dalam memberikan data. Sehingga penulis hanya mendapatkan data laporan keuangan tahunan dari website-website perusahaan asuransi syariah yang bersangkutan. Variabel dalam penelitian ini ialah :

a) Variabel Dependen

Variabel dependen dalam penelitian ini adalah kinerja keuangan yang diukur dengan Surplus On Contribution (SOC) 
b) Variabel Independen

Tabel 2 Variabel Independen Berdasarkan Penelitian Sebelumnya

\begin{tabular}{|c|c|c|c|}
\hline No & $\begin{array}{l}\text { Variabel } \\
\text { Independen }\end{array}$ & Cara Menghitung & Referensi \\
\hline $\mathrm{I}$ & $\begin{array}{l}\text { Size (Ukuran } \\
\text { Perusahaan) }\end{array}$ & Size $=$ Log Natural Total Asset & $\begin{array}{l}\text { Academic } \\
\text { International, Journal of } \\
\text { Management Research, } \\
\text { European Scientific Journal, e- } \\
\text { Journal Manajemen Fakultas } \\
\text { Ekonomi Universitas Trisakti }\end{array}$ \\
\hline 2 & Volume of Capital & $\begin{array}{l}\text { VOC = Log Natural Book } \\
\text { Valume of Capital }\end{array}$ & $\begin{array}{ll}\text { Academic } & \text { Research } \\
\text { International } & \\
\end{array}$ \\
\hline 3 & Leverage & $\begin{array}{l}\text { Leverage }=\text { Total } \\
\text { Liabilitas/Total Asset }\end{array}$ & $\begin{array}{l}\text { Journal of Management } \\
\text { Research, European Scientific } \\
\text { Journal }\end{array}$ \\
\hline 4 & Liquidity & $\begin{array}{l}\text { Liquidity }= \\
\text { Asset/Current Liabilitas }\end{array}$ & $\begin{array}{l}\text { Journal of Management } \\
\text { Research }\end{array}$ \\
\hline 5 & Tangibility (aset tetap) & $\begin{array}{l}\text { Tangibility = Fixed Asset/Total } \\
\text { Aset }\end{array}$ & European Scientific Journal \\
\hline 6 & $\begin{array}{l}\text { Loss Ratio (rasio } \\
\text { kerugian) }\end{array}$ & $\begin{array}{l}\text { Net Claim Incurred/Net Earned } \\
\text { Premium }\end{array}$ & European Scientific Journal \\
\hline
\end{tabular}

Dalam penelitian ini, analisis yang digunakan adalah analisis panel data multiple regression. Data panel atau pooled data merupakan kombinasi dari data time series dan cross section (Ajija, Sari, Setianto, \& Primanti, 20I I). Metode ini akan menjelaskan adanya keterkaitan antara variabel yang berkedudukan sebagai varibel independen dengan variabel dependen. Penelitian ini menggunakan 30 perusahaan asuransi syariah dengan periode 20I2-20I4 sebagai sampel penelitian serta 6 variabel independen (size, leverage, liquidity, tangibility, volume of capital, dan loss ratio) dan I variabel dependen (SOC) yang nilainya berbeda-beda dan akan diolah dengan menggunakan e-views 9 sebagai program pengolah data yang sudah didapatkan melalui dokumentasi maupun empirical research guna mendapatkan kesimpulan penelitian.

Keunggulan-keunggulan tersebut memiliki implikasi pada tidak harus dilakukan pengujian asumsi klasik dalam model data panel (Ajija, Sari, Setianto, \& Primanti, 20II). Tiga metode yang bisa digunakan untuk bekerja dengan data panel adalah sebagai berikut: Common Effect Model (CEM), Fixed Effect Model (FEM) dan Random Effect Model (REM) 
Dari tiga pendekatan data panel, dua pendekatan yang sering digunakan untuk mengestimasi model regresi dengan data panel adalah pendekatan FEM dan pendekatan REM. Uji F digunakan untuk menentukan metode antara pendekatan CEM dan FEM, sedangkan uji Hausman digunakan untuk menentukan antara REM dan FEM.

\section{HASIL DAN PEMBAHASAN}

Pemilihan Model Regresi Data Panel

Uji F-stat (Uji Chow) digunakan untuk menguji model terbaik antara Common Effect Model dengan Fixed Effect Model. Dari pengujian F-stat ini didapatkan hasil sebagai berikut:

Tabel 3 Hasil Redundant Fixed Effects Test- Likelihood Ratio

\begin{tabular}{lrrr}
\hline Effects Test & \multicolumn{1}{c}{ Statistic } & d.f. & Prob. \\
\hline Cross-section F & 2.190517 & $(29,54)$ & 0.0063 \\
Cross-section Chi-square & 69.990036 & 29 & 0.0000 \\
\hline
\end{tabular}

Sumber: Output Regresi Panel Data Eviews 9

Pada tabel diatas diketahui nilai probabilitas Cross-section Chi-square sebesar 0.0000 dan nilai ini lebih kecil dari tingkat signifikansi $5 \%(0,05)$, maka metode yang dipilih adalah metode Fixed Effect Model. Hasil ini belum merupakan hasil akhir atas metode pengolahan data karena belum teruji secara statisti. Oleh karena itu perlu melihat hasil dari metode lain yaitu Random Effect Model dan pengujiannya secara statistik.

Uji Hausman digunakan untuk membandingkan metode Fixed Effect Model dengan metode Random Effect Model. Hasil dari Uji Hausman ini adalah untuk mengetahui metode mana yang sebaiknya dipilih. Berikut ini adalah hasil output dari Uji Hausman :

Tabel 4 Hasil The Hausman Specification Test

\begin{tabular}{|lccc|}
\hline Test Summary & Chi-Sq. Statistic & Chi-Sq. d.f. & Prob. \\
\hline \hline & & & \\
Cross-section random & 27.901039 & 6 & 0.0001 \\
\hline
\end{tabular}

Sumber: Output Regresi Panel Data Eviews 9 
Berdasarkan hasil pengujian hausman diatas maka motode pilihan yang digunakan pada penelitian ini adalah metode Random Effect Model.

Pemilihan antara metode Fixed Effect Model dengan Random Effect Model menyarankan, jika data panel yang dimiliki mempunyai jumlah waktu (T) lebih besar dibanding jumlah individu $(\mathrm{N})(\mathrm{T}>\mathrm{N})$ maka disarankan untuk menggunakan Fixed Effect Model. Sedangkan jika data panel yang dimiliki mempunyai jumlah waktu (T) lebih kecil dibandin jumlah individu $(\mathrm{N})(\mathrm{T}<\mathrm{N})$ maka disarankan untuk menggunakan Random Effect Model (Nachrowi \& Usman, 2006). Menurut Nachrowi (2006) saran menggunakan Fixed Effect Model dengan Random Effect Model secara teoritis dan berdasarkan sampel data bukanlah sesuatu yang mutlak. Oleh karena itu, akan dilakukan perbandingan antara nilai-nilai statistik pada masing-masing metode. Berikut ini adalah perbandingan antara kedua output:

Tabel 5 Perbandingan Koefisien Determinasi Fixed Effect Model dengan Random Effect Model

\begin{tabular}{lcc}
\hline \multicolumn{1}{c}{ Model } & Fixed Effect & Random Effect \\
\hline R-squared & 0.551333 & 0.023713 \\
Adjusted R-squared & 0.260531 & -0.046862 \\
Prob(F-statistic) & 0.016805 & 0.916037 \\
\hline
\end{tabular}

Sumber: Output Regresi Panel Data Eviews 9

Pada tabel diatas diketahui bahwa pada Fixed Effect Model, R-squared nya mencapai 0.551333 yang berarti hubungan variabel dependent dapat dijelaskan oleh variabel independennya sebesar 55\%. Adjusted R-squared nya mencapai 0.260531 (26\%) dan F-statistiknya adalah 0.016805 (2\%). Angka ini menunjukan bahwa Fixed Effect Model adalah yang paling bagus untuk dijadikan model penelitian.

Adapun persamaan regresi dari hasil estimasi Fixed Effect Model adalah sebagai berikut:

SOC $=-1.805+810.39$ Size -355.32 Leverage +0.104 Liquidity +127.66 Tangibility 824.49 Volume of Capital + 0.06I Loss Ratio

Nilai konstanta atau intercept Surplus On Contribution (SOC) adalah I,805. Angka ini menunjukan bahwa jika variabel size, leverage, liquidity, tangibility, volume of capital dan loss ratio adalah tetap (konstan), maka maka akan menurunkan kinerja keuangan yang diukur oleh SOC sebesar I,805. 
Uji F (Simultan)

Uji-F digunakan untuk mengetahui apakah variabel independen yaitu size, leverage, liquidity, tangibility, volume of capital dan loss ratio secara bersama-sama berpengaruh atau tidak berpengaruh terhadap variabel dependen yaitu Surplus On Assets (SOC).

Hasil Uji-F pada tabel 5 diatas, menunjukan bahwa nilai pobabilitas F-Statistik sebesar 0.016805. Angka probabilitas F-Statistik ini lebih kecil dari tingkat signifikansi $5 \%(0,05)$ yang berarti bahwa semua variabel independen dalam penelitian ini berpengaruh secara simultan terhadap SOC.

Hasil dari penelitian ini dapat disimpulkan bahwa size, leverage, liquidity, tangibility, volume of capital dan loss ratio dapat berpengaruh terhadap SOC perusahaan-perusahaan asuransi syariah di Indonesia. Oleh karena itu, untuk perusahaan asuransi syariah yang ingin meningkatkan kinerja keuangannya, hendaknya melakukan analisis terhadap faktor-faktor yang mempengaruhi kinerja keuangan perusahaan seperti yang sudah dijelaskan diatas, sehingga dapat merumuskan strategi yang tepat untuk lebih meningkatkan kinerja keuangannya.

Uji-t (Individu)

Berikut ini adalah hasil Uji-t dari Fixed Effect Model dengan menggunakan eviews 9, yaitu:

Tabel 6 Uji-t (Individu)

\begin{tabular}{|crc|c|}
\hline Variable & Coefficient & Prob. & Keterangan \\
\hline \hline SZ & 810.3994 & 0.0000 & Signifikan \\
LV & -355.3215 & 0.0167 & Signifikan \\
LQ & 0.104874 & 0.8552 & Tidak signifikan \\
TA & 127.6624 & 0.5513 & Tidak signifikan \\
VOC & -824.4985 & 0.0000 & Signifikan \\
LOSS & 0.061754 & 0.9861 & Tidak signifikan \\
C & -1.805935 & 0.9968 & - \\
\hline
\end{tabular}

Sumber: Output Regresi Panel Data Eviews 9

Size

HI: Size (ukuran perusahaan) memiliki pengaruh positif terhadap kinerja keuangan perusahaan asuransi syariah di Indonesia. 
Berdasarkan hasil output regresi pada tabel diatas, variabel size sebesar 0.0000 . Angka ini lebih kecil dari tingkat signifikansi $(0,05)$ yang berarti menerima $\mathrm{HI}$ dan menolak HO. Angka ini menunjukan bahwa variabel size memiliki pengaruh positif yang signifikan terhadap terhadap kinerja keuangan (SOC). Hasil ini menunjukan bahwa semakin besar ukuran sebuah perusahaan asuransi, maka kinerja keuangannya juga semakin baik jika dibandingkan dengan perusahaan asuransi yang berukuran kecil. Perusahaan yang memiliki aset besar, seperti tersedianya sumber daya, staf yang kompeten dan sistem informasi yang baik akan membuat kinerja perusahaan asuransi semakin baik (Putri \& Lestari, 2014).

Berikut ini adalah perbandingan angka size dengan SOC perusahaanperusahaan asuransi syariah di Indonesia, yaitu:

\section{Grafik I Perbandingan size dengan SOC Perusahaan-Perusahaan}

\section{Asuransi Syariah di Indonesia}

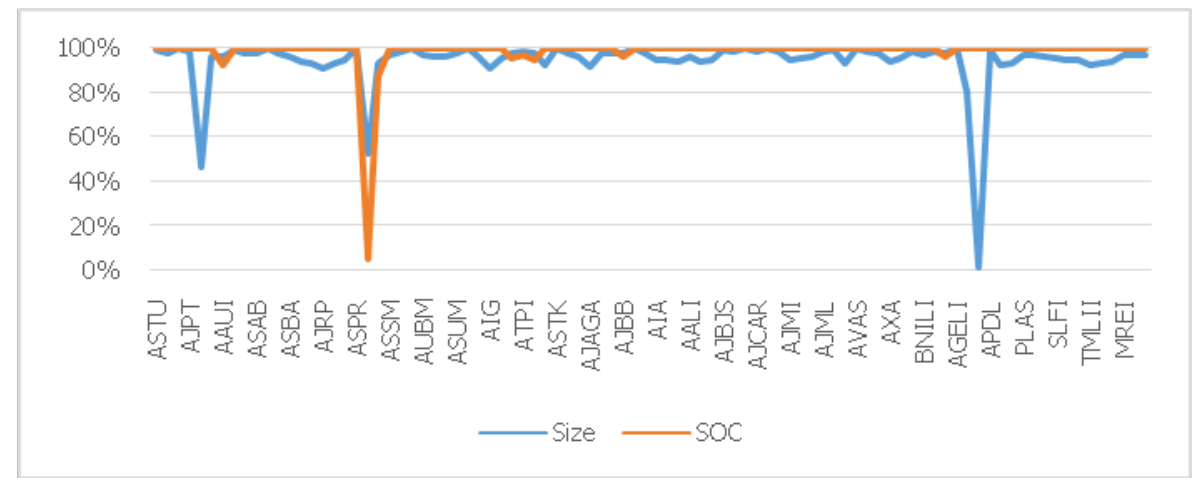

Sumber: Diolah (20I5)

Pada grafik diatas, diketahui bahwa pergerakan size perusahaan asuransi syariah diikuti dengan pergerakan SOC. Semakin tinggi angka size maka semakin tinggi pula angka SOC sebuah perusahaan asuransi syariah. Oleh karena itu, terbukti bahwa variabel size memiliki pengaruh positif terhadap kinerja keuangan yang diukur oleh SOC pada perusahaan-perusahaan asuransi syariah di Indonesia.

\section{Leverage}

H2: Leverage memiliki pengaruh positif terhadap kinerja keuangan perusahaan asuransi syariah di Indonesia.

Berdasarkan hasil output regresi pada tabel diatas, diketahui bahwa variabel leverage sebesar 0.0167. Angka ini lebih kecil dari tingkat signifikansi $(0,05)$ yang berarti menerima $\mathrm{H} 2$ dan menolak $\mathrm{H} 0$. 
Angka ini menunjukan bahwa variabel leverage memiliki pengaruh negatif terhadap kinerja keuangan (SOC). Hasil penelitian ini menunjukan rasio hutang yang negatif terhadap kinerja keuangan, artinya bahwa semakin tinggi rasio hutang yang dimiliki oleh sebuah perusahaan asuransi syariah, maka semakin buruk kinerja keuangannya. Dengan kata lain, semakin tinggi rasio hutangnya, maka akan menurunkan surplus perusahaan-perusahaan asuransi syariah di Indonesia. Berikut ini adalah perbandingan angka leverage dengan SOC perusahaan-perusahaan asuransi syariah di Indonesia, yaitu:

\section{Grafik 2 Perbandingan leverage dengan SOC Perusahaan-Perusahaan}

\section{Asuransi Syariah di Indonesia}

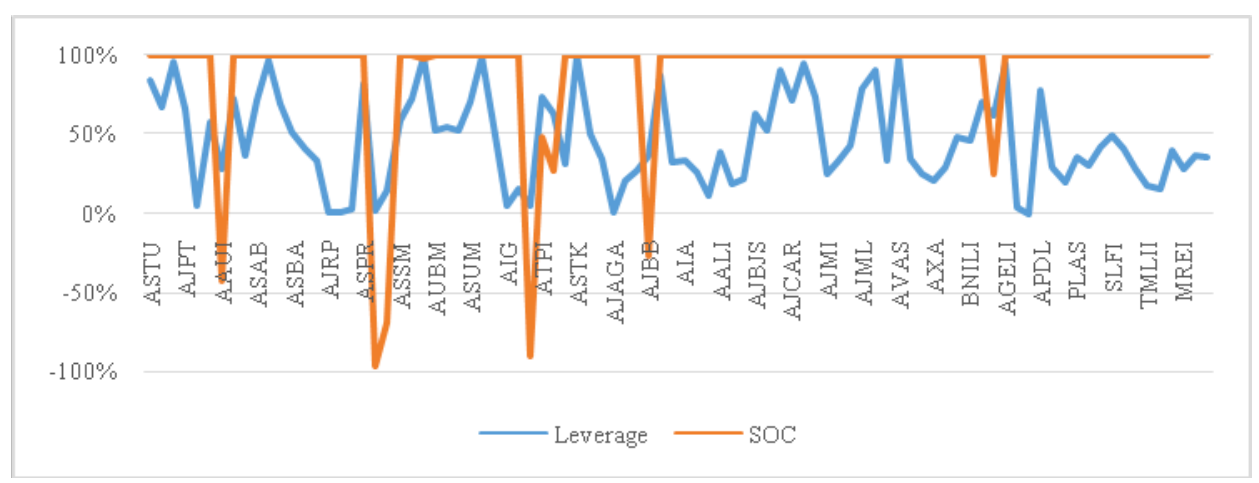

Sumber: Diolah (2015)

Dari grafik diatas, dapat diketahui bahwa pergerakan angka leverage perusahaan asuransi syariah selalu bertolak belakang dengan pergerakan angka SOC. Pada saat angka leverage tinggi maka angka SOC rendah, dan sebaliknya, ketika angka leverage rendah, maka angka SOC naik. Oleh karena itu, tinggi atau rendahnya rasio leverage terbukti berpengaruh secara negatif terhadap kinerja perusahan-perusahaan asuransi syariah di Indonesia.

\section{Liquidity}

H3: Liquidity memiliki pengaruh positif terhadap kinerja keuangan perusahaan asuransi syariah di Indonesia.

Berdasarkan hasil output regresi pada tabel diatas, variabel liquidity sebesar 0.8552. Angka ini lebih besar dari tingkat signifikansi $(0,05)$ yang berarti menerima $\mathrm{H} 0$ dan menolak H3. 
Angka ini menunjukan bahwa leverage tidak memiliki pengaruh yang yang signifikan terhadap kinerja keuangan. Hasil ini menunjukan bahwa likuiditas yang tinggi tidak berpengaruh terhadap kinerja keuangan perusahaan asuransi. Artinya, perusahaan asuransi dalam prosesnya lebih banyak menggunakan kewajiban jangka panjangnya dalam mendanai kegiatan operasionalnya dibandingkan dengan kewajiban jangka pendeknya.

Berikut ini adalah perbandingan angka liquidity dengan SOC perusahaanperusahaan asuransi syariah di Indonesia, yaitu :

Grafik 3 Perbandingan liquidity dengan SOC Perusahaan-Perusahaan

\section{Asuransi Syariah di Indonesia}

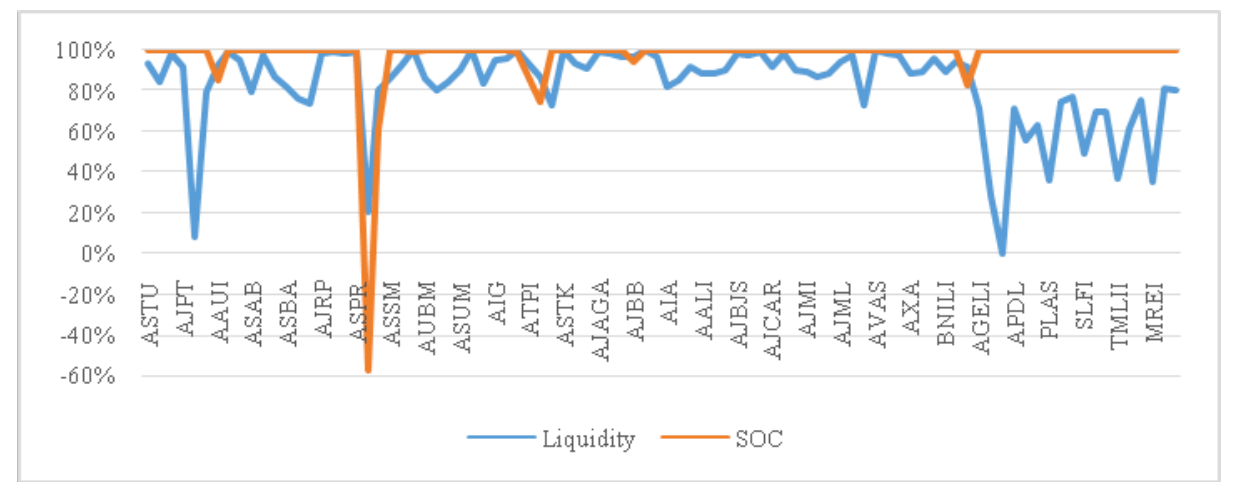

Sumber: Diolah (20I5)

Dari grafik diatas, diketahui bahwa pergerakan angka liquidity perusahaan asuransi syariah tidak selalu diikuti oleh pergerakan angka SOC. Pada saat angka liquidity tinggi, angka SOC cenderung sama saja. oleh sebab itu, pergerakan angka pada grafik diatas membuktikan bahwa tinggi atau rendahnya rasio liquidity sebuah perusahaan asuransi syariah di Indonesia tidak mempengaruhi kinerja keuangan perusahaan tersebut.

\section{Tangibility}

H4: Tangibility (aset tetap) memiliki pengaruh negatif terhadap kinerja keuangan perusahaan asuransi syariah di Indonesia.

Berdasarkan hasil output regresi pada tabel diatas, variabel tangibility sebesar 0.55 I3. Angka ini lebih besar dari tingkat signifikansi $(0,05)$ yang berarti menerima $\mathrm{H} 0$ dan menolak $\mathrm{H} 4$. 
Angka ini menunjukan bahwa variabel tangibility tidak memiliki pengaruh yang signifikan terhadap kinerja keuangan. Artinya bahwa kepemilikan aset tetap berwujud, tidak mempengaruhi kinerja keuangan sebuah perusahaan asuransi syariah. Atau dengan kata lain, kepemilikan intangible asset (aset tidak berwujud) juga akan mampu menghasilkan surplus yang lebih bagi perusahaan asuransi syariah. Berikut ini adalah perbandingan angka tangibility dengan SOC perusahaan-perusahaan asuransi syariah di Indonesia, yaitu :

\section{Grafik 4 Perbandingan tangibility dengan SOC Perusahaan-Perusahaan}

\section{Asuransi Syariah di Indonesia}

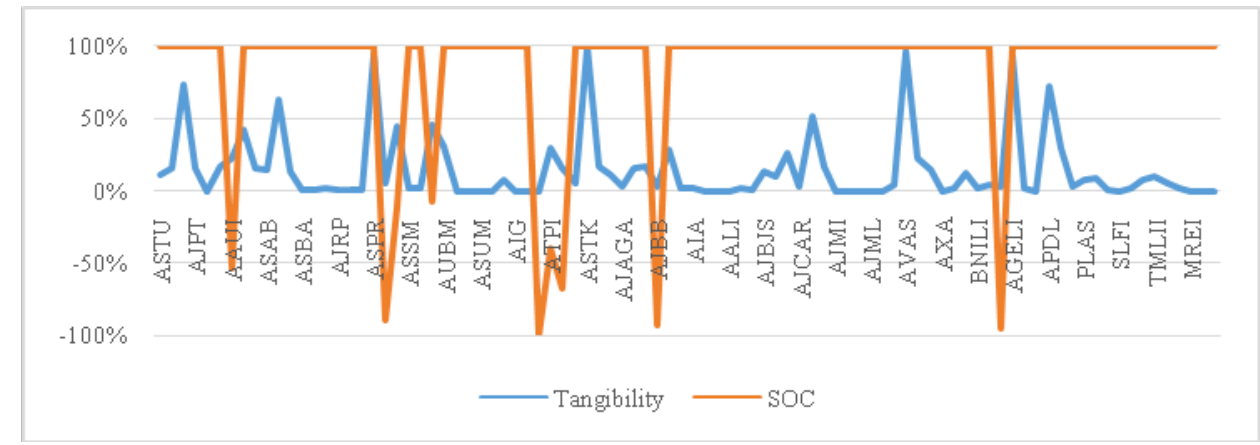

Sumber: Diolah (2015)

Dari grafik diatas, diketahui bahwa pergerakan angka tangibility perusahaan asuransi syariah tidak selalu diikuti oleh pergerakan angka SOC. Pada saat angka tangibility tinggi, angka SOC cenderung sama saja. oleh sebab itu, pergerakan angka pada grafik diatas membuktikan bahwa tinggi atau rendahnya rasio tangibility sebuah perusahaan asuransi syariah di Indonesia tidak mempengaruhi kinerja keuangan perusahaan tersebut.

\section{Volume of Capital}

H5: Volume of capital memiliki pengaruh positif terhadap kinerja keuangan perusahaan asuransi syariah di Indonesia.

Berdasarkan hasil output regresi pada tabel diatas, variabel volume of capital sebesar 0.0000 . Angka ini lebih kecil dari tingkat signifikansi $(0,05)$ yang berarti menerima H5 dan menolak H0. Hasil ini menunjukan bahwa volume of capital memiliki pengaruh negatif terhadap kinerja keuangan (SOC). Dimana, variabel ini tidak memiliki pengaruh terhadap kinerja keuangan perusahaan-perusahaan asuransi syariah di Indonesia. Artinya bahwa sebuah perusahaan asuransi yang tidak memiliki 
modal dengan jumlah besarpun akan mampu menghasilkan surplus yang akan meningkatkan kinerja keuangan perusahaan asuransi syariah tersebut. Berikut ini adalah perbandingan angka volume of capital dengan SOC perusahaan-perusahaan asuransi syariah di Indonesia, yaitu :

\section{Grafik 5 Perbandingan volume of capital dengan SOC Perusahaan-}

\section{Perusahaan Asuransi Syariah di Indonesia}

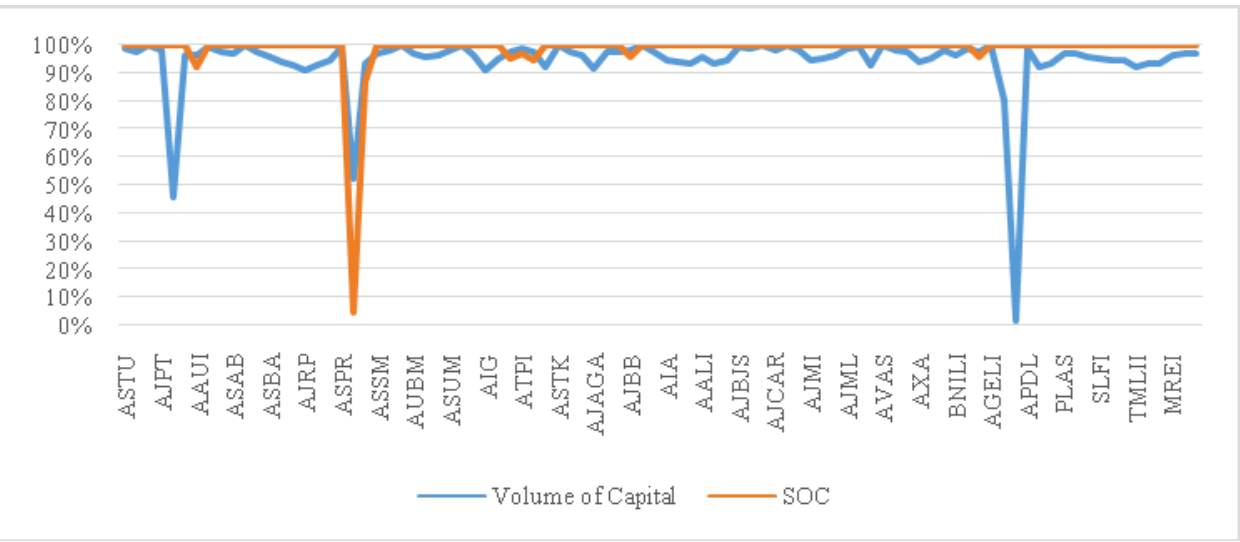

Sumber: Diolah (20I5)

Dari grafik diatas, dapat diketahui bahwa pergerakan angka volume of capital perusahaan asuransi syariah selalu bertolak belakang dengan pergerakan angka SOC. Pada saat angka volume of capital tinggi maka angka SOC rendah, dan sebaliknya, ketika angka volume of capital rendah, maka angka SOC naik. Oleh karena itu, tinggi atau rendahnya rasio volume of capital terbukti berpengaruh secara negatif terhadap kinerja perusahan-perusahaan asuransi syariah di Indonesia.

\section{Loss Ratio}

H6: Loss Ratio memiliki pengaruh negatif terhadap kinerja keuangan perusahaan asuransi syariah di Indonesia.

Berdasarkan hasil output regresi pada tabel diatas, variabel loss ratio sebesar 0.986I. Angka ini lebih besar dari tingkat signifikansi $(0,05)$ yang berarti menerima $\mathrm{H} 0$ dan menolak $\mathrm{H} 6$.

Angka ini menunjukan bahwa variabel loss ratio tidak memiliki pengaruh secara signifikan terhadap kinerja keuangan. Artinya bahwa rasio kerugian tidak memiliki pengaruh terhadap kinerja keuangan perusahaan asuransi, selama perusahaan tersebut mampu mengelola risiko sebelum menjadi kerugian yang nantinya akan 
berdampak terhadap kinerja keuangan. Berikut ini adalah perbandingan angka loss ratio dengan SOC perusahaan-perusahaan asuransi syariah di Indonesia, yaitu :

\section{Grafik 6 Perbandingan loss ratio dengan SOC Perusahaan-Perusahaan}

\section{Asuransi Syariah di Indonesia}

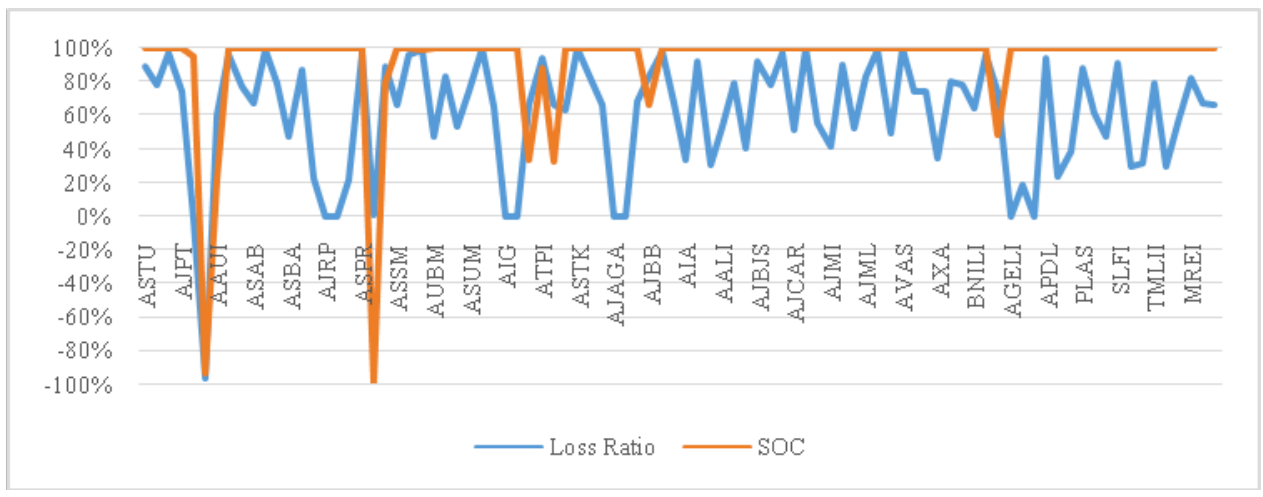

Sumber: Diolah (2015)

Dari grafik diatas, diketahui bahwa pergerakan angka loss ratio perusahaan asuransi syariah tidak selalu diikuti oleh pergerakan angka SOC. Pada saat angka loss ratio tinggi, angka SOC cenderung sama saja. oleh sebab itu, pergerakan angka pada grafik diatas membuktikan bahwa tinggi atau rendahnya loss ratio sebuah perusahaan asuransi syariah di Indonesia tidak mempengaruhi kinerja keuangan perusahaan tersebut.

\section{Uji Koefisien Determinasi}

Uji koefisien determinasi adalah suatu ukuran yang penting dalam regresi, karena dapat menginformasikan baik atau tidaknya model regresi yang terestimasi. (Nachrowi \& Usman, 2006). Nilai uji koefisien determininasi mencerminkan seberapa variasi dari variabel dependen (Y) dapat diterangkan oleh variabel independen $(X)$. Jika nilai koefisien determinasi sama dengan 0 artinya variabel variabel $Y$ tidak dapat diterangkan oleh variabel $X$ sama sekali. Sementara jika nilai koefisien determinasinya sama dengan I, artinya variasi dari $Y$ secara keseluruhan dapat diterangkan oleh $\mathrm{X}$.

Hasil uji koefisien determinasi pada penelitian ini (lihat tabel 4.II) adalah sebesar 0.541589. Angka ini menerangkan kekuatan variasi variabel independen terhadap variabel dependen dalam penelitian ini adalah sebesar 54\%. Hasil ini menunjukan arti yang lumayan kuat karena hampir mendekati I (satu), yang berarti 
bahwa variasi dari variabel dependen (SOC) secara keseluruhan dapat diterangkan oleh variabel independen (size, leverage, liquidity, tangibility, volume of capital dan loss ratio).

\section{SIMPULAN}

Kinerja keuangan yang diukur oleh SOC menunjukan bahwa variabel size, leverage, liquidity, tangibility, volume of capital dan loss ratio secara simultan berpengaruh terhadap kinerja keuangan (SOC). Secara parsial variabel size, leverage, dan volume of capital terbukti secara statistik berpengaruh signifikan terhadap kinerja keuangan (SOC) perusahaan-perusahaan asuransi syariah di Indonesia. Hasil ini menunjukan bahwa size memiliki pengaruh positif terhadap kinerja keuangan (SOC). Sedangkan leverage dan volume of capital berpengaruh negatif terhadap kinerja keuangan perusahaan-perusahaan asuransi syariah di Indonesia. Variabel lainnya, yaitu liquidity, tangibility dan loss ratio secara statistik tidak berpengaruh signifikan terhadap kinerja keuangan (SOC) perusahaan-perusahaan asuransi syariah di Indonesia

\section{PUSTAKA ACUAN}

Aemiro, M. D. (20I3). Firm Specific Factors That Determine Insurance Companies' Performance In Ethiopia . European Scientific Journal, 245-255.

Ahmed, N. (2010). Determinants Of Performance: A Case Of Life Insurance Of Pakistan. European Jurnal of Economis, Finance and Administrative Sciences, 24 : 7-12.

Ajija, S., Sari, D. W., Setianto, R. H., \& Primanti, M. R. (20I I). Cara Cerdas Menguasai EViews. Jakarta: Salemba Empat.

Almajali, A. Y. (2012). Factors Affecting the Financial Performance of Jordanian Insurance Companies Listed at Amman Stock Exchange. Journal of Management Research Vol. 4, No. 2, 194I-899X.

Amanah Githa Asuransi Jiwa Syariah. (2016, Februari Selasa). Asuransi Berdasarkan Prinsip Syariah. Retrieved from www.amanahgitha.com: www.amanahgitha.com/www/index/php?page=product-detail\&\&id=26 
Bandi. (2007). Financial Statement Analysis. Semarang: UNS.

Fatwa DSN MUI. (200I). Fatwa No. 2IIDSN-MUI/X/200I tentang Pedoman Umum Asuransi Syariah. Jakarta: DSN MUI.

Gill, O. J., \& Chatton, M. (2003). Memahami Laporan Keuangan (understanding financial statement). Jakarta: Victory Jaya Abadi.

Hana, O. D. (20I5, November Sabtu). OJK : Penetrasi Asuransi Syariah Masih 0,08 \%. Retrieved from www.bisnis.com: http://m.bisnis.com/finansial/read/20 I 5 I I07/2 I5/489923/ojk-penetrasiasuransi-syariah-masih-008-hingga-september-20I5

Hanson, R., \& Mowen, M. (2005). Management Accounting 7 edition. Singapore: SouthWestern.

Hasbi, H. (20I3). Sistem Peringatan Dini Sebagai Pendukung Kinerja Perusahaan Asuransi Syariah. Jurnal Keuangan dan Perbankan, Vol.I 7, No.2 , 243-252.

Havnes, P., \& Senneseth, K. (200I). Panel Study of Firm Growth Among SMEs In Networks Mall Bussines Economic.

Hery. (2012). Analisis Laporan Keuangan. Jakarta: PT Bumi Aksara.

Himalaya Insurance. (2016, Februari Selasa). Prospek dan Tantangan Asuransi Syariah di Indonesia. Retrieved from www.himalayains.com: http://www.himalayains.com/index.php/latest-news/insuranceknowledge/492-prospek-dan-tantangan-asuransi-syariah-di-indonesia

Hosen, M. N., Ali, A. H., \& Muhtasib, A. B. (2008). Materi Dakwah Ekonomi Syariah . Jakarta: PKES (Pusat Komunikasi Ekonomi Syariah).

IAI. (20I3). Pemegang SAS. Retrieved 03 23, 20I4, from Sertifikasi Ikatan Akuntan Indonesia (Sertifikasi IAI): http://iaisertifikasi.blogspot.com/p/pemegangcpsak.html?view=snapshot

Ikatan Akuntan Indonesia. (2008). PSAK IOI Penyajian Laporan Keuangan Syariah. Jakarta: DSAK IAI.

IKNB. (2015, September Senin). Jumlah Asuransi Syariah Terus Meningkat. Retrieved from Syariah Finance Com (Referensinya Keuangan Syariah): http://www.syariahfinance.com/iknb/275-jumlah-perusahaan-asuransi-syariahterus-meningkat.html 
Imran, M. S., Ahmad, A., \& Bhuiyan, M. Z. (20I2). Auditing in Islamic Perspective and Auditing as Practiced in some selected Islamic Banks Operating in Bangladesh. IIUC STUDIES, 9, 293-306.

Institute of Chartered Accountants. (2005). Agency theory and the role of audit. England and Wales: Institute of Chartered Accountants.

Karim Consulting Indonesia. (20I4). Islamic Finance Outlook 20I5. Jakarta: Karim consulting Indonesia.

Kuncoro, M. (2003). Metode Riset Untuk Bisnis dan Ekonomi. Jakarta: PT. gelora Aksara Pratama.

Mahsun, M., Sulistiyowati, F., \& Purwanugraha, H. A. (20I I). Akuntansi Sektor Publik. Yogyakarta: BPFE-YOGYAKARTA.

Malik, H. (20II). Determinants Of Insurance Companies Profitability : An Analysis Of Insurance Sector Of Pakistan. Academic Research Internasional Volume I, issue 3,, 2223-9553.

Mehari, D., \& Aemiro, T. (2013). Firm Specific Factors That Determine Insurance Companies' Performance In EthiopiA. European Scientific Journal edition vol. 9, No. 10, 1857-7431.

Mokhtar, H. S., Aziz, I. A., \& Hilal, N. M. (20I5). Surplus Sharing Practices Of Takaful Operators In Malaysia. ISRA International Journal of Islamic Finance. Vol. 7. Issues I, 99-1 26.

Munawir, S. (1995). Analisa Laporan Keuangan. Yogyakarta: Liberty Yogyakarta.

Mysharing.co. (2015). Ekonomi Syariah akan Lebih Baik pada 20I5. Retrieved from My Sharing Berita Ekonomi \& Keuangan Syariah.

Nachrowi, D. N., \& Usman, H. (2006). Pendekatan Populer dan Praktis Ekonometrika Untuk Analisis Ekonomi dan Keuangan. Jakarta: Fakultas Ekonomi Universitas Indonesia.

Omang. (2012, Desember Tuesday). 2013 Dinilai Tahunnya Asuransi Syariah. Retrieved from www.republika.co.id: http://indo2.islamicworld.net/index.php?option=com_content $\&$ view $=$ article\&id $=243$ 
PMK Nomor 18/ PMK.010/20I0. (2010). Penerapan prinsip Dasar penyelenggaraan usaha Asuransi dan Usaha Reasuransi Dengan prinsip Syariah. Jakarta: Menteri Keuangan Republik Indonesia.

PSAK 108 Akuntansi Asuransi Syariah. (2008). Jakarta: DSAK IAI.

Pusat Komunikasi Ekonomi Syariah. (2008). Materi Dakwah Ekonomi Syariah. Jakarta: PKES (Pusat Komunikasi Ekonomi Syariah).

Putri, A. P., \& Lestari, H. S. (20/4). Faktor-faktor yang menentukan kinerja perusahaan asuransi yang terdaftar di bursa efek indonesia. e-journal manajemen fakultas ekonomi, volume I nomor 2, I-20.

Respati. (2014, Desember). Pertumbuhan Asuransi Syariah Pada Tahun 2015 Bergantung Pada Faktor-Faktor Ini. Retrieved from MySharing.Co: http://mysharing.co/pertumbuhan-asuransi-syariah-pada-20I5-bergantungpada-faktor-faktor-ini/\&ei

Subramanyam, K., \& Wild, J. J. (20II). Analisis Laporan Keuangan . Jakarta: Salemba Empat.

UPKFE. (20II). Modul Eviews 6. Semarang: UPKFE (Unit Pengembangan Fakultas Ekonomika UNDIP. 